\title{
STRATEGI PEMERINTAH DALAM UPAYA MENINGKATKAN \\ PEMBERDAYAAN EKONOMI MASYARAKAT \\ DI KECAMATAN BARA KOTA PALOPO
}

\author{
Mahadin Shaleh ${ }^{1}$ \\ Muhammad Hafid Fadillah ${ }^{2}$ \\ mahadinsaleh@gmail.com
}

\begin{abstract}
Main Research Issues This thesis discusses: "Government Strategy in Efforts to Improve Community Economic Empowerment in Bara District, Palopo City" with the following problems: 1. What is the socio-economic condition of the people of the bara sub-district? 2. What is the government's strategy in empowering the people of the bara sub-district? 3. What is the impact of government empowerment on economic improvement? This research aims to: a. To know and analyze the socio-economic conditions b. To find out and analyze the government's strategy in increasing community empowerment in the bara district c. To find out and analyze the impact of government empowerment on economic improvement. To obtain data, the author uses field research methods and library research which then analyzes the data using a qualitative method and then draws conclusions with the analysis technique (SWOT) Strengths Weaknesses Opportunities and Threats. Based on the results of the study, it shows that: 1.In building the economy of the people in Bara District, by looking at the efforts made by the government to increase the potential for each community, it is very positive that the existence of government efforts can motivate the community to be able to develop in addition to being good training., the community will be considered capable of increasing the potential and opportunities in the community's economy. 2. With the existence of a strategy carried out by the government through business assistance, it is very evident that this business is able to increase the level of income for the community while the businesses that have been implemented include: business selling food stalls, selling chips business, fish selling business, sewing machine business, vegetable farmer business., a thousand chicken coops business, and a workshop business. 3. An increase in efforts to empower the community has a very positive impact and the government is considered capable of improving the welfare of the community so that business assistance carried out by the government can change every community's life for the better.
\end{abstract}


Keywords: Government Strategy, Efforts to Improve Community Economic Empowerment.

\begin{abstract}
ABSTRAK
Permasalahan Pokok Penelitian skripsi ini adalah membahas tentang: "Strategi Pemerintah dalam Upaya Meningkatkan Pemberdayaan Ekonomi Masyarakat di Kecamatan Bara Kota Palopo" dengan masalah sebagai berikut: 1. Bagaimana kondisi sosial ekonomi masyarakat kecamatan bara? 2. Bagaimanakah strategi pemerintah dalam pemberdayaan masyarakat kecamatan bara? 3. Bagaimana dampak pemberdayaan pemerintah terhadap peningkatan ekonomi?.Penelitian ini bertujuan: a. Untuk mengetahui dan menganalisis kondisi sosial ekonomi b. Untuk mengetahui dan menganalisis strategi pemerintah dalam meningkatkan pemberdayaan masyarakat di kecamatan bara c. Untuk mengetahui dan menganalisis dampak pemberdayaan pemerintah terhadap peningkatan ekonomi. Untuk memperoleh data, penulis menggunakan metode field research dan library research yang kemudian menganalisa data dengan menggunakan cara kualitatif kemudian mengambil kesimpulan dengan teknik analisis (SWOT) Strengths (Kekuatan) Weaknesses (Kelemahan) Opportunities (Peluang) dan Threats (Ancaman). Berdasarkan hasil penelitian menunjukkan bahwa: 1. Dalam membangun perekonomian masyarakat yang ada di Kecamatan Bara dengan melihat adanya upaya yang dilakukan pemerintah untuk meningkatkan potensi bagi setiap masyarakat sangatlah memberikan respon positif dengan adanya usaha pemerintah dapat memotivasi masyarakat untuk mampu berkembang disamping dapat menjadi pelatihan yang baik, masyarakat akan dianggap mampu untuk meningkatkan potensi dan peluang dalam ekonomi masyarakat. 2. Dengan adanya strategi yang dilakukan pemerintah melalui bantuan usaha sangat terbukti bahwa usaha tersebut mampu untuk menambah tingkat pendapatan bagi masyarakat adapun usaha yang sudah terlaksana diantaranya yaitu: usaha warung jualan, usaha penjualan keripik, usaha penjualan ikan, usaha mesin jahit, usaha petani sayur, usaha seribu kandang ayam, dan usaha perbengkelan. 3. Adanya peningkatan usaha dalam memberdayakan masyarakat sangat berdampak positif dan pemerintah dianggap mampu dalam meningkatkan kesejahteraan masyarakat sehingga bantuan usaha yang dilakukan pemerintah dapat merubah setiap kehidupan masyarakat kearah yang lebih baik.
\end{abstract}

Kata Kunci : Strategi Pemerintah, Upaya Meningkatkan Pemberdayaan Ekonomi Masyarakat. 


\section{PENDAHULUAN}

Bicara mengenai pemberdayaan masyarakat tidak dapat dilepaskan dari persoalan kemiskinan sebagai objek dari pemberdayaan itu sendiri. Pemberdayaan mempunyai filosofi dasar sebagai suatu cara mengubah masyarakat dari yang tidak mampu menjadi berdaya. ${ }^{1}$ Indonesia adalah sebuah Negara yang subur akan kekayaan alamnya yang melimpah. Namun sebagian besar rakyat tergolong miskin. Krisis ekonomi tahun 1998-1999 penduduk miskin di Indonesia mencapai sekitar $24 \%$ dari jumlah penduduk. Atau hampir 40 juta orang. Tahun 2002 angka tersebut sudah turun menjadi 18\% dan sangat diharapkan menjadi 14\% pada tahun 2004. Tetapi siapa yang dapat menjamin bahwa jumlah penduduk miskin akan terus menurun. ${ }^{2}$ Berikut sekilas tentang darurat kemiskinan yang terjadi di kota palopo menurut sekertaris pemerintah bapak Taufik mengatakan warga miskin mencapai 37.000 jiwa mulai tanggal 30 januari 2015. Musafir Jasin mengatakan bahwa kemiskinan berdasarkan jumlah penduduk kota palopo ditahun 2013 sebesar 160.800 jiwa maka angka tersebut sebesar 23\% dari jumlah penduduk. Kenaikan ini sangatlah signifikan dari 14.800 penduduk miskin. Tahun 2012 naik menjadi 15.500 jiwa, tahun 2013 dan ditahun 2015 perode 2014 menyentuh angka 37.000 jiwa ini berarti terjadi kenaikan tajam selama setahun ini sebesar 21.500 jiwa. $^{3}$ Menurut kabid ekonomi Aliaman Rahmat menyebutkan jumlah penduduk warga miskin di Kecamatan Bara densus tahun 2013 berdasarkan jumlah RT di Kecamatan Bara sebesar 1.049 jiwa dan individu sebanyak 4.982 jiwa. $^{4}$ Adapun upaya-upaya yang dilakukan pemerintah dalam meningkatkan pemberdayan bagi masyarakat adalah bertujuan untuk membuat masyarakat menjadi mandiri, dalam arti masyarakat memiliki potensi untuk mampu memecahkan masalah-masalah yang mereka hadapi, dan sanggup memenuhi kebutuhannya dengan baik. Pemerintah dituntut untuk menghargai hak-hak masyarakat yaitu hak untuk menentukan sendiri, untuk memilih apa yang terbaik bagi masyarakat serta hak untuk

memperoleh kesempatan yang sama berkembang sesuai dengan potensi-potensi yang masyarakat miliki. ${ }^{5}$

Tujuan yang ingin dicapai dalam pemberdayaan masyarakat menurut Sulistiyani adalah membentuk individu dan masyarakat menjadi mandiri. Kemandirian tersebut meliputi kemandirian berfikir, bertindak, dan mengendalikan apa yang mereka lakukan tersebut. untuk mencapai kemandirian masyarakat sangatlah diperlukan sebuah proses. Melalui proses belajar maka secara bertahap masyarakat akan memperoleh kemampuan atau daya dari waktu kewaktu. ${ }^{6}$ Data diatas menjelaskan bahwa masyarakat merupakan potensi yang dapat dikembangkan dengan melihat potensi yang ada pada diri masyarakat maka tahapan-tahapan yang harus dilalui yaitu dengan memberikan pelatihan yang baik bagi masyarakat, maka masyarakat akan mampu di untuk berdayakan sesuai dengan potensinya masing-masing. Individu merupakan bagian dari masyarakat. Masyarakat dapat dikatakan sebagai kumpulan 
dari beberapa individu. Kesejahteraan dalam pembentukan individu yang sempurnah menjadi konsen utama dalam kebahagiaan masyarakat juga merupakan cerminan dari kebahagiaan individu. ${ }^{7}$ Ekonomi hanyalah merupakan satu bagian dari aspek kehidupan yang diharapkan akan membawa manusia kepada tujuan hidupnya. Adalah untuk mencapai falah sebagai tujuan hidup bagi masyarakat yaitu kemuliaan dan kemenangan dalam hidup. Istilah falah menurut Islam diambil dari kata Al-Quran, yang sering dimaknai sebagai keberuntungan jangka panjang, dunia dan akhirat, sehingga dalam konteks dunia falah merupakan konsep yang memiliki aspek perilaku individual. Kehidupan dunia falah mencakup tiga pengertian yaitu kelangsungan hidup, kebebasan berkeinginan, serta kekuatan dan kehormatan. Sedangkan untuk kehidupan akhirat falah juga mencakup tiga pengertian yaitu kelangsungan hidup yang abadi, kesejahteraan abadi, dan pengetahuan abadi. Untuk memperoleh suatu kelangsungan hidup masyarakat maka di dalam aspek mikro ada tiga faktor manusia ingin membutuhkan kelangsungan hidup dalam masyarakat:

1. Pemenuhan kebutuhan biologis seperti kesehatan fisik atau bebas dari penyakit.

2. Faktor ekonomis misalnya memiliki sarana kehidupan.

3. aktor sosial misalnya adanya persaudaraan, hubungan yang baik dan harmonis antara sesama manusia.

Aspek makro juga memiliki tiga faktor yaitu:

1. Kesejahteraan dan keseimbangan.

2. ingkungan yang higienis.

3. Kerja sama antar anggota masyarakat.

Faktor-faktor ini baru akan lengkap jika manusia juga terbebas dari kemiskinan serta memiliki kekuatan dan kehormatan. ${ }^{8}$ Dari paparan tersebut dapat disimpulkan bahwa tujuan pemberdayaan adalah memampukan dan memandirikan masyarakat terutama dari Kemiskinan biasanya terjadi karena individu tidak mampu memberdayakan potensi dirinya secara mandiri. Kemiskinan yang diderita oleh masyarakat bukan hanya masalah kecerdasan tetapi juga bermasalah dalam keahlian hidup karena tanpa keahlian hidup manusia tidak akan mendapatkan peluang untuk memenangkan perlombaan hidup yang semakin keras. ${ }^{9}$ Oleh karena itu, penulis tertarik untuk menulis skripsi ini dengan judul:"Strategi Pemerintah Dalam Upaya Meningkatkan Pemberdayaan Ekonomi Masyarakat Di kecamatan Bara Kota Palopo"

Bertolak dari latar belakang masalah diatas, maka dapat dirumuskan permasalahan sebagai berikut :

1. Bagaimana kondisi sosial ekonomi masyarakat Kecamatan Bara?

2. Bagaimanakah strategi pemerintah dalam pemberdayaan masyarakat Kecamatan Bara? 
3. Bagaimana dampak pemberdayaan pemerintah terhadap peningkatan ekonomi?

Definisi Operasional yang digunakan dalam penelitian ini adalah dari penentuan data variabel penelitian tersebut diatas, penulis mencoba memberikan definisi terhadap variabel tersebut untuk menghindari adanya interpretasi dan penafsiran yang berbeda.

1. Pemberdayaan ekonomi masyarakat Kecamatan Bara adalah suatu proses pemberdayaan yang berupaya membangun daya masyarakat dengan mendorong, memotivasi dan membangkitkan kesadaran akan potensi ekonomi yang masyarakat miliki. Adanya kesadaran dan potensi masyarakat akan mempermudah pemerintah dalam memberikan bantuan usaha kepada masyarakat sehingga dapat membuat perekonomian masyarakat menjadi maju dan berkembang.

2. Strategi pemerintah adalah suatu proses pemikiran yang berupaya untuk melihat masalah-masalah pada masyarakat sehingga masyarakat mampu untuk dikembangkan

dengan mudah adanya pemerintah dapat membantu masyarakat dalam meningkatkan potensi dan peluang dalam ekonomi. ${ }^{10}$

3. Sosial ekonomi masyarakat adalah suatu ilmu yang mempelajari aktivitas manusia yang berhubungan dengan ekonomi. Manusia merupakan mahluk sosial karena dalam ruang lingkup sosial pada dasarnya manusia selalu menghadapi masalah dalam ekonomi. Masalah ekonomi yang dihadapi manusia kenyataan bahwa kebutuhan manusia jumlahnya tidak terbatas. Sedangkan alat pemuas kebutuhan manusia jumlahnya terbatas. ${ }^{11}$

4. Peningkatan ekonomi adalah secara umum merupakan peningkatan yang berupaya untuk menambah derajat, tingkat dan kualitas dalam ekonomi agar masyarakat mampu mengembangkan setiap usaha-usaha yang dilakukannya sehingga masyarakat menjadi sejahtera dalam kehidupannya. ${ }^{12}$

\section{Tinjauan Teoritis}

\section{A. Pengertian Strategi Pemberdayaan}

Strategi pemberdayaan merupakan terjemahan dari kata (empowerment) sedangkan memberdayakan merupakan terjemahan kata dari (empower) beberapa literatur menyebutkan bahwa konsep pemberdayaan sudah lahir sejak zaman revolusi industri atau pada abad ke 16 (renaisance). ${ }^{13}$ Menurut Dhal (1963) mengatakan bahwa pemberdayaan yang berasal dari kata empowerment sangat berkaitan dengan kekuatan atau kekuasaan (power) karena itu pemberdayaan dapat diartikan sebagai upaya untuk meningkatkan kekuatan atau kemampuan (daya) seseorang untuk dapat memengaruhi orang lain agar selalu berlaku adil. 
Strategi pertama kali digunakan dalam dunia militer sedangkan organisasi pemerintah baru mulai menerapkan strategi pada pertengahan tahun 60 sampai dengan tahun 70an salah satu alasan mengapa pentingnya mempelajari strategi adalah strategi sebagai suatu kerangka kerja (frame work) yang dapat digunakan untuk menyelesaikan setiap masalah yang ada dalam suatu organisasi pemerintah atau perusahaan terutama yang berkaitan dengan persaingan. Strategi secara umum merupakan salah satu teknik untuk mendapatkan kemenangan (victory) dalam mencapai suatu tujuan yang telah ditetapkan (to achieve goals). ${ }^{14}$ Menurut Chandler (1962) mendefenisikan strategi adalah tujuan jangka panjang dari suatu organisasi atau perusahaan. Serta pendayagunaan dan alokasi semua sumberdaya yang sangat penting dalam mencapai suatu tujuan.

Data diatas menjelaskan bahwa dengan adanya strategi yang baik dalam pemberdayaan masyarakat akan sangat mempermudah pemerintah dalam mengembangkan setiap potensi masyarakat. Adanya strategi dapat memberikan pengetahuan kepada setiap pemikir atau pemerintah dalam melakukan pembinaan yang baik kepada setiap masyarakat yang memiliki kemampuan untuk berkembang sesuai dengan potensinya masing-masing.

Pemberdayaan masyarakat dalam pasal 1 ayat 8 Permendagri RI Nomor 7 Tahun 2007 yaitu: ${ }^{15}$ Menyatakan bahwa pemberdayaan masyarakat adalah suatu strategi yang digunakan dalam pembangunan masyarakat sebagai upaya untuk mewujudkan kemampuan dan kemandirian dalam kehidupan bermasyarakat berbangsa dan bernegara. Secara konseptual, strategi pemberdayaan sering diartikan dengan beragam pendekatan yaitu: ${ }^{16}$

1. Strategi sebagai suatu rencana

2. Strategi sebagai kegiatan

3. Strategi sebagai pola pikir

B. Pemberdayaan Ekonomi Masyarakat Tinjauan Ekonomi Islam

Pemberdayaan dalam perspektif ekonomi islam dapat dipahami sebagai salah satu cabang ilmu ekonomi yang bertujuan untuk membangun manusia seutuhnya. Dalam membangun kesejahteraan yang seimbang bekerja dan berusaha merupakan salah satu hal yang sangat pokok yang harus dipenuhi agar dapat mencapai tujuan dalam hidup masyarakat. Adapun pandangan ekonomi islam dalam memandang pemberdayaan masyarakat dapat dilihat dari tiga prinsip elemen dasar yang mampu memberikan pandangan serta arah yang baik bagi setiap masyarakat di antaranya yaitu: ${ }^{17}$

1. tolong menolong dalam setiap kebaikan

2. kerja sama yang baik antara pemerintah dan masyarakat. Dalam arti pemerintah menjalankan kewajibannya sebagai seorang pemimpin dan masyarakat menerima haknya sebagai masyarakat dan sebaliknya masyarakat harus menunaikan apa yang

menjadi kewajibannya dan pemerintah juga menerima haknya sebagai seorang 
pemimpin

3. keadilan. Dalam setiap Kecamatan Bara itu terdiri dari lima Kelurahan. dan dari lima kelurahan tersebut kita ketahui bersama bahwa pemerintah Kecamatan Bara harus bisa berlaku adil dalam memberikan bantuan usaha terhadap lima kelurahan yang ada di Kecamatan Bara. Sebagaimana diketahui bahwa menciptakan suatu kerja sama dan tolong-menolong sesama manusia adalah anjuran dalam agama. al-Qur'an telah menganjurkan akan adanya kerja sama dan tolong-menolong. itu hanya dilakukan dalam kebaikan dan mencerminkan ketakwaan kepada Allah Swt. ${ }^{18}$ Barikut ini adalah ayat yang berhubungan dengan tolong menolong yaitu: Q.S. al-Ma'idah/5 :2

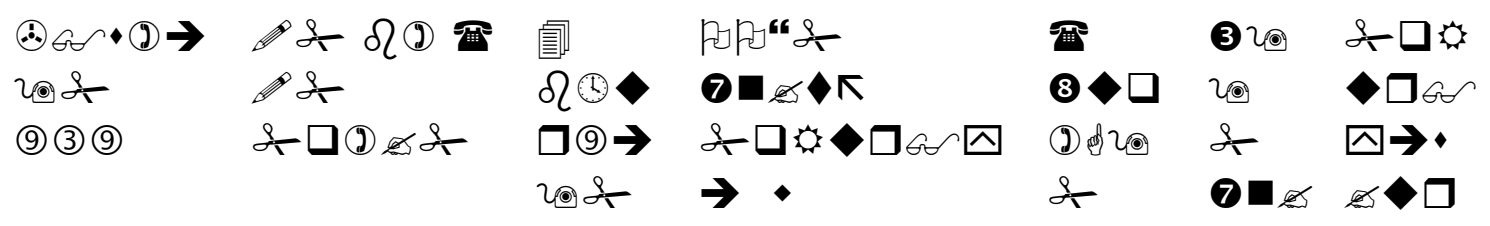


Terjemahnya:

Dan tolong-menolonglah kamu dalam mengerjakan kebajikan dan takwa, dan jangan tolong-menolong dalam berbuat dosa dan pelanggaran. dan bertakwalah kamu kepada Allah Swt, sesungguhnya Allah Swt amat berat siksa-nya. ${ }^{19}$

Data diatas menjelaskan bahwa ayat tersebut sangatlah baik untuk kita jadikan sebagai contoh dalam kehidupan sehari-hari karena ayat tersebut menjelaskan tentang pentingnya saling tolong-menolong dalam kebaikan karena didalam setiap kehidupan manusia hidup dengan sendiri-sendiri tanpa membutuhkan bantuan dari orang lain sangatlah sulit untuk dilakukan untuk itu Allah Swt sangatlah menyayangi bagi setiap hambanya yang hidup dengan saling membantu antara sesama umatnya dalam melakukan kebaikan.

\section{Pemerintahan}

Menurut kamus besar bahasa Indonesia (KBBI) pemerintah diartikan sebagai sistem menjalankan wewenang dengan bersama-sama memikul tugas dan tanggung jawab untuk menggunakan kekuasaannya dalam mengatur setiap kehidupan sosial ekonomi masyarakat. ${ }^{20}$

Kamus bahasa Inggris, govern (memerintah), sebagai kata kerja, berasal dari kata latin gubernare yang artinya mengemudikan (sebuah kapal), yang menunjukkan metode atau sistem pengemudian atau manajemen dalam organisasi. Kata kerja govern digunakan dalam bidang politik, yang kata bendanya menjadi government dalam arti luas. Menurut kamus bahasa inggris, istilah government dapat diartikan pemerintah dan dapat juga diartikan pemerintahan. ${ }^{21}$ Pengertian pemerintah secara terminologis yaitu:

1. Pemerintah dalam arti luas adalah semua lembaga Negara sebagaimana yang diatur dalam UUD disuatu Negara.

2. Pemerintah dalam arti luas ialah semua lembaga konstitusi Negara yang bersangkutan disebut sebagai pemegang kekuasaan pemerintahan. Indonesia kedudukannya berada diwilayah UUD 1945. Kekuasaan pemerintahan meliputi fungsi legislatif (pemerintahan Negara dalam arti luas adalah gabungan alat-alat kelengkapan Negara legislative yaitu DPR) dan fungsi eksekutif (pemerintah dalam arti sempit yang memegang kekuasaan atau birokrasi aparat pemerintah yang terpilih melalui pemilihan

\footnotetext{
${ }^{25}$ Depertemen agama RI. Al-Kamil, op.cit h 251
} 
oleh lembaga perwakilan yang terdiri dari presiden, wakil presiden,dan kabinet atau dewan mentri).

D. Upaya Pemerintah dalam Meningkatkan Ekonomi Masyarakat

Upaya Pemerintah dalam Pemberdayaan di bidang ekonomi. Merupakan pemberdayaan yang berupaya untuk membangun daya masyarakat dengan mendorong, memotifasi dan membangkitkan kesadaran akan potensi ekonomi yang masyarakat miliki. Upaya dalam pengelolaan sumberdaya untuk mengembangkan potensi ekonomi masyarakat akan meningkatkan potensi bagi setiap individu. ${ }^{22}$ Individu dan masyarakat akan mampu menghasilkan dan menumbuh kembangkan nilai tambah yang baik dan mampu meningkatkan kemakmuran dan kesejahteraan ekonomi bagi pemberdayaan masyarakat. Peranan pemerintah dalam upaya meningkatkan pemberdayaan bagi masyarakat dapat dilihat dari tiga sisi yaitu: ${ }^{23}$

1. Dengan menciptakan sarana yang memungkinkan bagi masyarakat berkembang maka didalam titik pemikirannya adalah pengenalan bahwa setiap individu atau masyarakat akan dapat memiliki potensi yang mampu untuk dikembangkan dengan baik. Contohnya yaitu: upaya pemerintah untuk mengembangkan potensi ekonomi bagi masyarakat dengan memberikan sedikit bantuan bagi masyarakat miskin melalui usaha mikro kecil menengah (UMKM) maka masyarakat yang belum bekerja sudah menjadi berdaya karena adanya bantuan dari pemerintah.

2. Memperkuat potensi ekonomi atau daya yang dimiliki oleh masyarakat. upaya yang sangat pokok adalah meningkatkan usaha bagi masyarakat serta terbukanya kesempatan untuk memanfaatkan peluang dalam ekonomi.

3. Memberdayakan mengandung pula arti melindungi dalam proses pemberdayaan perlu adanya perlindungan pemerintah untuk mencegah terjadinya persaingan yang tidak seimbang serta mencegah perkembangan ekonomi yang kuat atas yang lemah.

E. Model Pemberdayaan Ekonomi Islam

Allah Swt telah memberikan petunjuk kepada umat manusia bagaimana menjadi insan kamil atau petunjuk agama islam yang sempurnah. secara garis besar ajaran agama islam dikelompokkan dalam dua kategori, hablum minallah yaitu hubungan vertikal antara manusia dengan Allah Swt dan hablum minannas yaitu hubungan manusia dengan manusia. Allah Swt sangat menghendaki kedua hubungan tersebut seimbang walaupun hablum minannas lebih banyak ditekan namun itu semua bukan berarti lebih mementingkan urusan kemasyarakatan, namun hal itu tidak lain karena hablum minannas lebih lengkap dan lebih menyeluruh. ${ }^{24}$ Berikut ini adalah ayat yang berhubungan dengan sosial masyarakat yaitu: Q.S. al-Ra'd/13 :11

\footnotetext{
${ }^{25}$ Depertemen agama RI. Al-Kamil, op.cit h 251
} 


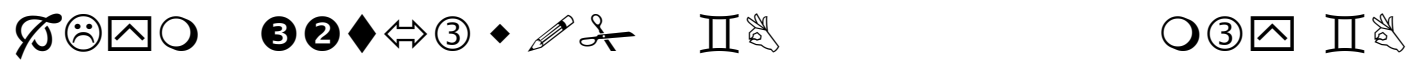 \\ 十口・(1) m(1) 目 \& \& 2 है (1) $\mathrm{O}$ (1)





Terjemahnya:

Bagi manusia ada malaikat-malaikat yang selalu menjaganya bergiliran, dari depan dan belakangnya. mereka menjaganya atas perintah Allah. Sesungguhnya Allah tidak mengubah keadaan sesuatu kaum sebelum mereka mengubah keadaan diri mereka sendiri dan apabila Allah menghendaki keburukan terhadap suatu kaum, maka tidak ada yang dapat menolaknya, dan tidak ada pelindung bagi mereka selain Allah Swt. ${ }^{25}$

${ }^{24}$ Darrussalam, Ayat-ayat Al-Quran tentang sosial masyarakat dalam https:// bidsosdarussalam.wordpress. com (Akses tgl 26 juni 2015)

\footnotetext{
${ }^{25}$ Depertemen agama RI. Al-Kamil, op.cit h 251
} 
Hal ini sesuai dengan peraturan perundang-undangan yang berlaku di Indonesia yaitu pada Pasal 33 UUD Tahun 1945. ${ }^{26}$

1. Perekonomian disusun sebagai usaha bersama berdasar atas asas kekeluargaan.

2. Cabang-cabang produksi yang penting bagi Negara dan menguasai hajat hidup orang banyak dikuasai oleh Negara

3. Bumi, air dan kekayaan alam yang terkandung didalamnya dikuasai Negara dan dipergunakan untuk sebesar-besarnya bagi kemakmuran rakyat.

4. Dan ayat yang berhubungan dengan jiwa dan pemeliharaan Q.S. at-Tariq/86:4

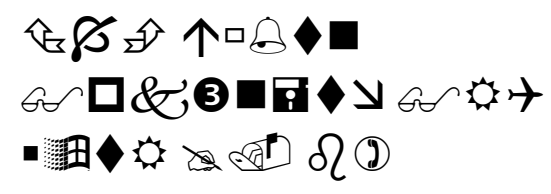

Terjemahnya:

Setap jiwa pasti ada pemeliharanya. ${ }^{27}$

Kandungan ayat diatas menurut M. Quraish Shihab dalam bukunya tafsir alMishbah. $^{28}$ dalam segala aktifitas yang dilakukan manusia semua itu tidak lepas dari pengawasan Allah Swt yang selalu menjaga manusia baik diwaktu pagi maupun malam. Allah Swt telah memberikan jiwa dan pemeliharaan bagi setiap manusia agar manusia saling menghargai antara sesamanya. Manusia selalu terjaga dan terlindungi disamping itu Allah Swt juga memberikan tugas bagi para malaikat-malaikatnya untuk menjaga setiap pemeliharaan itu baik yang ada di langit maupun yang ada di bumi seperti pemeliharaan terhadap jiwa dan pemeliharaan sarana dan prasarana kehidupan seperti udara, air, matahari dan sebagainya. Data diatas menjelaskan bahwa dari dua ayat diatas sangatlah baik untuk kita jadikan sebagai pedoman karena ayat dan penjelasannya yang sangat rinci membuat penulis sangat tertarik untuk membahas ayat ini karena ayat yang pertama menjelaskan tentang pentingnya bekerja dan berusaha dalam segala sesuatu yang kita lakukan dan ayat yang kedua menjelaskan tentang pentingnya menjaga persaudaraan antara sesama manusia karena setiap apa yang dilakukan manusia tidak lepas dalam pengawasan Allah Swt. Dalam setiap kehidupan Allah Swt telah menetapkan manusia sebagai mahluk yang paling sempurnah dan yang paling mulia disisi Allah Swt.

\footnotetext{
${ }^{27}$ Depertemen agama RI. Al-Kamil, op.cit. h 592

${ }^{28}$ M. Quraish Shihab, op.cit h 566
} 
Mahadin Saleh Dan Muhammad Hafid Fadillah : Startegi Pemerintah....................................... 96

${ }^{26}$ Sanusi Fattah dkk, Ilmu Pengetahuan Sosial (Jakarta: PT. Ghalia Indonesia Printing 2008) h 315

${ }^{27}$ Depertemen agama RI. Al-Kamil, op.cit. h 592

${ }^{28}$ M. Quraish Shihab, op.cit h 566 


\section{F. Kerangka Pikir}

Pemberdayaan ekonomi merupakan suatu usaha pemerintah untuk meningkatkan kesejahteraan masyarakat dengan adanya usaha bagi pemerintah masyarakat akan merasa mudah untuk diberdayakan dalam hubungan sosial ekonomi upaya yang harus dikembangkan pemerintah yaitu dengan mengadakan pelatihan kepada masyarakat agar masyarakat bisa berkembang sesuai dengan potensi ekonomi yang masyarakat miliki serta mampu untuk meningkatkan pemberdayaan ekonomi dengan menerapkan skill dan keahlian bagi masyarakat. Berdasarkan hal tersebut diatas maka penulis akan mencoba memberikan gambaran kerangka pikir yang dapat menghantar dalam pembahasan yang telah ditentukan.

Kerangka pikir tersebut disajikan dalam bentuk diagram sebagai berikut:

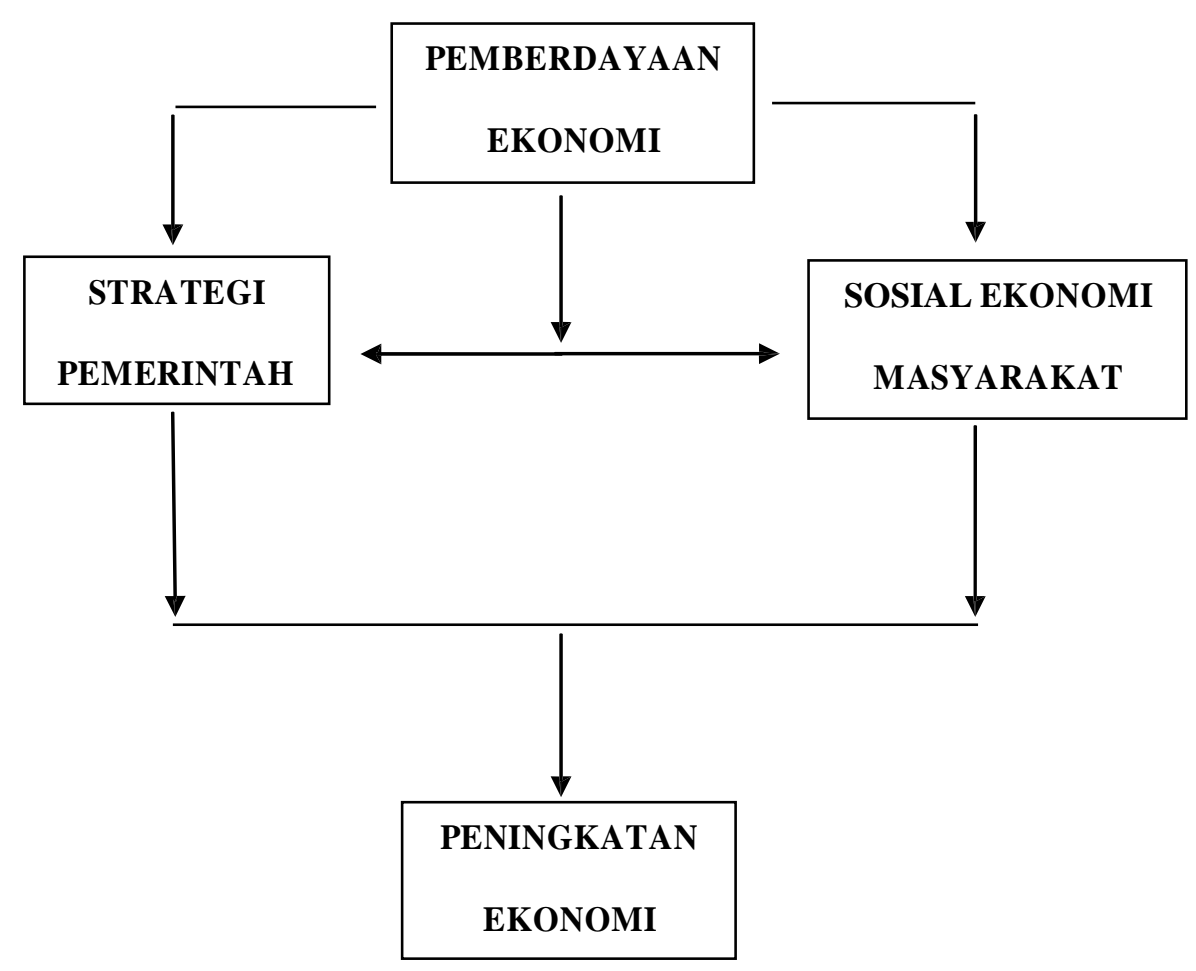

Dari bagian kerangka pikir diatas dapat diuraikan sebagai berikut:

Dalam seluruh aspek kehidupan masyarakat, keberdayaan dan kemandirian masyarakat merupakan cerminan dalam kehidupan sosial masyarakat yang tidak dapat dilepaskan dari nilai-nilai peningkatan ekonomi masyarakat yang berupaya untuk mensejahterakan masyarakat melalui tugas pemerintah sangat diharapkan agar masyarakat mampu mengembangkan potensi ekonominya dengan baik. 


\section{Metode Penelitian}

\section{A. Jenis Penelitian Dan Pendekatan}

Dalam penelitian ini penulis menggunakan metode kualitatif dengan pendekatan sosial ekonomi adalah pendekatan yang memperhatikan kedudukan atau posisi seseorang dalam kehidupan sosial masyarakat karena dalam kehidupan manusia tidak akan bisa hidup dengan sendiri-sendiri tanpa membutuhkan bantuan orang lain sehingga dalam pendekatan sosial ekonomi penulis dapat dengan mudah melihat masalah-masalah yang terjadi di lingkungan sosial ekonomi masyarakat. $^{29}$

B. Lokasi Penelitian

Adapun lokasi yang akan dijadikan tempat penelitian yaitu Kantor Dinas Kecamatan Bara Kota Palopo dan dikalangan masyarakat.

C. Sumber Data

1. Data primer ${ }^{30}$

Data primer adalah data yang diperoleh secara langsung dari sumber yang diteliti.

Yang dilakukan dengan cara wawancara langsung kepada narasumber peneitian yakni pegawai kantor dan masyarakat kecamatan bara kota palopo.

2. Data Sekunder

Data sekunder adalah data yang diperoleh dari pihak tertentu yang sangat berhubungan dengan penelitian. Data yang diperoleh dengan cara:

a. Pencatatan yaitu dengan mencatat laporan-laporan yang mendukung dari penelitian.

b. Studi kepustakaan yaitu dengan membaca referensi yang berhubungan dengan objek penelitian atau dari internet dan buku-buku yang dianggap relevan terutama dalam hal menunjang tinjauan teoritis sosial terhadap penulisan skripsi ini.

D. Populasi Dan Sampel

1. Populasi

Dalam metode penelitian kata populasi digunakan sebagai subjek penelitian menurut Winarno Surakhmad Populasi adalah keseluruhan objek penelitian yang terdiri dari manusia, gejala, nilai test, benda-benda ataupun peristiwa sebagai sumber data yang

\footnotetext{
${ }^{29}$ Moehar Daniel Metode penelitian sosial ekonomi (Jakarta: Penerbit Bumi Aksara 2002-2003) h 6-7

${ }^{30}$ Winarno Surakhmad. Pengantar penelitian Ilmiah dasar metode dan teknik (Bandung: Penerbit Tarsito 2001) h 134
} 
memiliki karakteristik tertentu dalam suatu penelitian. ${ }^{31}$ Berdasarkan pengertian ini populasi yang dimaksud oleh penulis dalam penelitian ini adalah pemerintah kecamatan dan kelurahan bara serta masyarakat yang ada di kecamatan bara kota palopo yang menjadi sasaran objek dalam penelitian penulis menggunakan objek tertentu berupa data di Kecamatan Bara Kota Palopo.

2. Sampel

Berdasarkan populasi yang ada di kecamatan bara kota palopo sesuai dengan maksud penelitian maka dalam menentukan sampel penulis memfokuskan objek penelitian melalui Camat atau yang mewakili, Lurah atau yang mewakili, Ketua RT dan RW, Tokoh Masyarakat, Tokoh Pemuda dan pelaku usaha berdasarkan jenis pemiliknya masing-masing dengan menggunakan metode snowball sampling yakni pengambilan sampel menurut orang-orang yang dipilih dan akan disesuaikan dengan maksud penelitian. $^{32}$ Namun dengan keterbatasan dana dan waktu maka peneliti tidak mengambil semua jumlah populasi yang ada.

E. Teknik Pengumpulan Data

Dalam proses pengumpulan data, penulis menggunakan beberapa tehnik sebagai berikut:

1. Field Research, yaitu pengumpulan data yang berkaitan dengan judul skripsi ini langsung dalam lokasi penelitian. Berikut ada beberapa tehnik yang digunakan sebagai berikut:

a. Observasi yang dilakukan adalah dengan memperoleh informasi tentang hubungan sosial dalam masyarakat dengan mencermati aspek dan tujuan dalam kehidupan kemudian menarik masalah dengan melakukan pendekatan terhadap individu dan masyarakat. Dalam hal ini peneliti terlebih dahulu mengamati masalah yang dipilih kemudian dapat dipecahkan dengan baik. ${ }^{33}$

b. Wawancara

Wawancara yaitu sebagai alat informasi yang dilakukan dengan cara mengajukan sejumblah pertanyaan kepada narasumber yang dilakukan dengan cara lisan dengan demikian hasil dari wawancara tersebut akan diolah kemudian dikumpulkan bersama dengan pengolahan data yang lain.

c. Dokumen yaitu catatan terdahulu yang merupakan peristiwa. Kemudian dapat diarsipkan dalam bentuk tulisan, gambaran atau karya-karya dari seseorang.

\footnotetext{
${ }^{31}$ Winarno Surakhmad, Ibid. h 93

${ }^{32}$ S. Nasution, Metode Research Penelitian Ilmiah (Jakarta: PT Bumi Aksara 2008) Ed.1Cet.10 h 98-99

${ }^{33}$ S. Nasution, Ibid. h 106
} 
2. Library research, yaitu metode pengumpulan data yang dilakukan dengan cara membaca buku-buku yang tertuju pada proposal skripsi. Dengan ini penulis menggunakan tehnik pengutipan sebagai berikut:

a. Kutipan langsung, adalah mengutip tanpa merubah redaksi teks yang dikutip sebagaimana dengan teks aslinya.

b. Kutipan tidak langsung, adalah mengutip dengan hanya mengambil intisari atau makna dari teks yang dikutip tanpa mengikuti redaksi yang aslinya.

F. Analisis Data

Moleong menyimpulkan bahwa analisis data adalah proses mengorganisasikan dan mengurutkan data kedalam pola, kategori, satuan uraian dasar sehingga dapat ditemukan tema dan dirumuskan hipotesis kerja sebagaimana yang disarankan oleh data. ${ }^{34}$ Strategi pemerintah berdasarkan analisis (SWOT) Strengths (kekuatan), Weaknesses (kelemahan), Opportunities (peluang) dan Threats (ancaman). Analisis ini terbagi menjadi dua yaitu Internal Faktor Evaluation (IFE) dan Eksternal Faktor Evaluation (EFE). IFE di gunakan untuk mengetahui faktor Internal dalam pemberdayaan masyarakat yang berkaitan dengan kekuatan dan kelemahan yang sangat penting untuk diketahui. Berikut ada beberapa bagian strategi yang sangat penting untuk kita ketahui yaitu: ${ }^{35}$

1. Strategi SO (Strengths Opportunies)

Strategi untuk memanfaatkan kekuatan internal masyarakat untuk meraih peluang pemerintah.

2. Strategi WO (Weaknesses Opportunies)

Strategi untuk memperkecil berbagai kelemahan internal masyarakat untuk tetap memanfaatkan peluang pemerintah.

3. Strategi ST (Strengths Threats)

Strategi untuk memanfaatkan kekuatan internal masyarakat untuk mengatasi berbagai ancaman yang berasal dari luar pemerintah.

4. Strategi WT (Weaknesses Threats)

Strategi untuk memperkecil berbagai kelemahan internal masyarakat dan menghindari berbagai ancaman yang berasal dari luar pemerintah.

\footnotetext{
${ }^{34}$ Menurut Lexy J. Moleong (Bandung: Penerbit PT Remaja Rosda Karya 1988) Ed 1 Cet 10 h 189

${ }^{35}$ Freddy Rangkuti, Analisis SWOT Teknik Membedah Kasus Bisnis (Jakarta:PT Gramedia Pustaka Utama 2004) h 31-32
} 


\section{Hasil Penilitian}

\section{A. Kondisi Sosial Ekonomi Masyarakat Kecamatan Bara}

Menurut kepala seksi pembangunan dan perekonomian dan kesos kecamatan bara Armia Karim mengatakan bahwa kondisi sosial ekonomi masyarakat yang ada di kecamatan bara dengan melihat potensi ekonomi yang ada dapat memberikan sebuah nilai tambah bagi masyarakat karena usaha tersebut dapat dikembangkan dengan melihat bantuan yang telah dilakukan pemerintah seperti bantuan usaha warung jualan, usaha penjualan keripik, usaha penjualan ikan, usaha mesin jahit, usaha petani sayur, usaha seribu kandang ayam, dan usaha perbengkelan yang dapat membantu usaha masyarakat sehingga pendapatan masyarakat dapat meningkat dan kesejahteraan masyarakat dapat terwujud. ${ }^{36}$

Data diatas menjelaskan bahwa dari pendapat di atas mengenai kondisi sosial ekonomi masyarakat Kecamatan Bara maka penulis mengamati kondisi sosial ekonomi masyarakat yang ada di kecamatan bara sangatlah menjanjikan bagi setiap usaha karena dengan melihat adanya kondisi sosial ekonomi masyarakat di Kecamatan Bara untuk menentukan situasi dan kondisi setiap orang pemerintah harus bisa menentukan setiap potensi usaha yang baik bagi masyarakat untuk dapat dikembangkan sehingga dapat menjadikan potensi usaha sebagai nilai dalam meningkatkan pendapatan usaha masyarakat. Dalam pandangan ilmu ekonomi manusia tercipta sebagai makhluk yang paling sempurnah diantara makhluk lainnya. Dengan dibekali nafsu, naluri, akal dan hati. Meskipun demikian manusia sering kali memiliki keterbatasan namun dengan keterbatasan itu manusia bisa menutupi dirinya dengan jalan untuk mencari kebutuhan yang harus dipenuhi. ${ }^{37}$ Didaerah kecamatan bara dalam pengamatan penulis melihat keterbukaan masyarakat mengenai bantuan usaha sangatlah mendukung penuh bagi masyarakat dengan melihat adanya usaha masyarakat sangat termotivasi untuk mau berkembang sehingga pemerintah memberikan solusi bagi masyarakat dengan memberikan bantuan usaha kepada masyarakat dan memberikan pelatihan serta motivasi yang baik agar setiap usaha yang diberikan pemerintah akan mudah untuk dikelola bagi setiap masyarakat. Menurut Rahmawati Rahim dengan adanya program UB di kecamatan dan kelurahan bara maka masyarakat akan mampu untuk mengembangkan setiap usaha Karena potensi usaha yang ada di kecamatan bara dapat menjanjikan dan mampu untuk dikembangkan dengan

\footnotetext{
${ }^{36}$ Armia Karim, SE. Kepala Seksi Pembangunan Dan Perekonomian dan Kesos Kecamatan Bara, (Wawancara Tanggal 11 Januari 2016)

${ }^{37}$ Burhanuddin dkk, op.cit $\mathrm{h} 8$
} 
melihat potensi dan peluang dalam ekonomi masyarakat. Dengan masuknya bantuan usaha, masyarakat sangat termotivasi untuk menjalankan usaha yang diberikan pemerintah. Dalam hal ini pemerintah kecamatan bara bekerjasama dengan kelurahan bara juga sangat antusias penuh dalam memberikan bantuan kepada masyarakat. potensi ekonomi masyarakat yang ada dikecamatan bara sangatlah komplit, terpelajar dan menjanjikan untuk usaha. Dengan adanya bantuan pemerintah masyarakat dapat berkembang dengan baik sesuai dengan potensinya. Disamping dapat menjadi pelatihan bagi masyarakat, dapat juga menjadi penghasilan dan nilai tambah bagi masyarakat. Untuk itu pemerintah sangat mengharapkan bagi setiap masyarakat agar perekonomiannya lebih baik dalam menjalankan setiap bantuan usaha dari pemerintah. ${ }^{38}$ Ada tiga nilai komponen dasar yang harus mampu diterapkan dalam diri setiap manusia agar dapat mencapai apa yang diharapkan yaitu keperibadian, sikap dan emosi. ${ }^{39}$ Dalam diri setiap manusia khususnya bagi para pemimpin dalam lembaga pemerintahan atau camat kecamatan bara dalam menjalankan tugas dan tanggung jawab yang besar tidaklah mudah untuk dilakukan. Sebagai agen perubahan untuk mencapai tujuan yang diinginkan diperlukan adanya dorongan yang kuat dari setiap perwakilan lembaga pemerintahan. Dalam menjalankan peran utama yang harus dibangun dari seorang pemimpin ini adalah memengaruhi dan memotivasi orang lain untuk secara sukarela dapat mencapai sasaran yang telah ditetapkan sehingga pemimpin dapat menciptakan visi dan menginspirasi orang lain. Untuk mencapai visi dalam tujuan tersebut ada empat devenisi untuk mencapai tujuan dalam kepemimpinan kecamatan dalam kelembagaan organisasi pemerintahan diantaranya yaitu:

1. Kepemimpinan adalah merupakan kemampuan memengaruhi orang lain dengan menggunakan kekuasaannya

2. Kepemimpinan adalah suatu proses interaksi antara pemimpin dan pengikut

3. Kepemimpinan terjadi pada berbagai tingkat dalam suatu organisasi kelembagaan

4. Kepemimpinan memfokuskan pada penyelesaian tujuan bersama

Adapun Visi Dan Misi pemerintahan kecamatan bara dalam melaksanakan tugas pemerintahan, pembangunan dan kemasyarakatan mempunyai visi dan misi yang merupakan acuan dalam melaksanakan tugas pelayanan dengan sebaik-baiknya diantaranya yaitu: ${ }^{40}$ 2016)

${ }^{38}$ Rahmawati Rahim, S. AN. Operator Computer Kantor Kel Belandai, (Wawancara Tanggal 30 Januari

${ }^{39}$ Wibowo, op.cit h $15-49-75$

${ }^{40}$ Arsip data program dan kegiatan Kecamatan Bara Tahun 2012, 2013 dan 2015 
1. Visi

Visi merupakan pandangan jauh kedepan yang dapat memberikan inspirasi dan motivasi kerja bagi masa depan organisasi. Dengan visi organisasi akan memperoleh gambaran yang jelas tentang arah serta masa depan organisasi. Bertolak dari uraian tersebut diatas, maka rumusan visi kantor kecamatan bara adalah" Terwujudnya Pelayanan Prima Pada Kantor Kecamatan Bara Menuju Masyarakat Sejahtera Dan Damai".

2. Misi

Untuk mencapai Visi tersebut diatas maka ditetapkan Misi:

a. Mengembangkan kualitas SDM aparatur dalam upaya memberikan pelayanan yang memuaskan masyarakat.

b. Menciptakan kondisi yang aman dan kondusif untuk mendukung aktivitas perekonomian masyarakat.

c. Membangun kesadaran beragama dan partisipasi masyarakat dalam pembangunan.

d. Mengedepankan norma dan budaya lokal dalam penyelenggaraan pemerintahan kecamatan.

e. Mengoptimalkan kegiatan pemberdayaan dan pengayoman kepada masyarakat serta mempertahankan budaya gotong royong.

B. Strategi Pemerintah Dalam Pemberdayaan Masyarakat Kecamatan Bara

Menurut ismawati mengatakan bahwa strategi merupakan susunan sistem rencana yang dapat memberikan dorongan penting agar dapat mencapai tujuan yang telah ditetapkan. Untuk dapat mencapai tujuan tersebut pemerintah sekaligus sebagai pasilitator dalam membangun perekonomian masyarakat harus mampu memberikan motivasi dan dorongan yang kuat agar masyarakat mampu untuk menghidupi setiap kebutuhan dalam ekonomi. ${ }^{41}$

Data diatas menjelaskan bahwa untuk membangun perekonomian masyarakat yang harus dibutuhkan pemerintah sebagai pengatur dalam membangun perekonomian masyarakat yaitu dengan membuka pengetahuan masyarakat akan pentingnya motivasi dan pelatihan yang baik dalam setiap usaha untuk dapat mengembangkan setiap potensi masyarakat langkah yang harus dibangun bagi setiap pemerintah yaitu harus mampu memengaruhi setiap masyarakat akan pentingnya pengelolaan usaha dan pengembangan akan pentingnya usaha bagi masyarakat sehingga masyarakat akan mampu untuk mengembangkan setiap potensi dan keahliannya masing-masing. Menurut pengamatan penulis dalam upaya meningkatkan

\footnotetext{
${ }^{41}$ Ismawati, S. Pd Tokoh Masyarakat, (Wawancara Tanggal 16 Januari 2016)
} 
pemberdayaan bagi masyarakat peran pemerintah sudah betul bagus dalam meningkatkan perekonomian masyarakat karena setiap bantuan pemerintah yang diberikan kepada masyarakat selama dapat difungsikan dengan baik, maka pemerintah dalam membangun perekonomian masyarakat dapat dikatakan mampu dalam membuka pengetahuan masyarakat sehingga setiap bantuan usaha disamping dapat menjadi penghaasilan masyarakat dan dapat juga menjadi nilai tambah bagi masyarakat. berikut ini adalah gambaran tabel data pelaku usaha pemerintah yang masih tetap berjalan di kecamatan dan kelurahan bara yaitu:

\begin{tabular}{|c|c|c|c|c|c|}
\hline NO & $\begin{array}{l}\text { Nama Pemilik } \\
\text { Usaha }\end{array}$ & $\begin{array}{l}\text { Jenis Bantuan } \\
\text { Usaha }\end{array}$ & $\begin{array}{c}\text { Jumlah Pendapatan } \\
\text { Sebelum } \\
\text { Diberdayakan } \\
\end{array}$ & $\begin{array}{c}\text { Jumlah Pendapatan } \\
\text { Sesudah } \\
\text { Diberdayakan } \\
\end{array}$ & Keterangan \\
\hline 1 & Geiman G.P & Warung Jualan & 500.000 & 1.200 .000 & Meningkat \\
\hline 2 & Lenni & Warung Jualan & 800.000 & 1.500 .000 & Meningkat \\
\hline 3 & Afdal & Warung Jualan & 300.000 & 1.250 .000 & Meningkat \\
\hline 4 & Sarding & Warung Jualan & 550.000 & 2.000 .000 & Meningkat \\
\hline 5 & Abdul Rahman & Warung Jualan & 700.000 & 1.800 .000 & Meningka \\
\hline 6 & Helmi & Penjualan Keripik & 600.000 & 1.250 .000 & Meningkat \\
\hline 7 & Suriani & Penjualan Keripik & 400.000 & 1.000 .000 & Meningkat \\
\hline 8 & Penni & Penjualan Keripik & 500.000 & 1.000 .000 & Meningkat \\
\hline 9 & Santi & Penjualan Ikan & 700.000 & 1.000 .000 & Meningkat \\
\hline 10 & Rahma & Penjualan Ikan & 500.000 & 1.200 .000 & Meningkat \\
\hline 11 & Muzakkar & Mesin Jahit & 1.000 .000 & 3.000 .000 & Meningkat \\
\hline 12 & Irma & Mesin Jahit & 600.000 & 2.100 .000 & Meningkat \\
\hline 13 & Jabbar & Petani Sayur & 500.000 & 1.000 .000 & Meningkat \\
\hline 14 & Hasbiati & Petani Sayur & 300.000 & 1.250 .000 & Meningkat \\
\hline 15 & Mildawati & $\begin{array}{c}\text { Seribu Kandang } \\
\text { Ayam }\end{array}$ & 500.000 & 1.200 .000 & Meningkat \\
\hline 16 & Sukri Sukma & $\begin{array}{c}\text { Seribu Kandang } \\
\text { Ayam }\end{array}$ & 420.000 & 1.150 .000 & Meningkat \\
\hline 17 & Rita & $\begin{array}{c}\text { Seribu Kandang } \\
\text { Ayam }\end{array}$ & 600.000 & 1.100 .000 & Meningkat \\
\hline 18 & Andi Arifuddin & $\begin{array}{c}\text { Seribu Kandang } \\
\text { Ayam }\end{array}$ & 500.000 & 1.130 .000 & Meningkat \\
\hline 19 & Ilham & Perbengkelan & 300.000 & 1.000 .000 & Meningkat \\
\hline 20 & Arifuddin & Perbengkelan & 500.000 & 1.200 .000 & Meningkat \\
\hline
\end{tabular}




\section{Rumus:}

Pendapatan Perbulan $=$ TP - TB X 30

Contoh sampel dari hasil wawancara penulis:

1. a.) Sebelum di berdayakan:

$$
\begin{aligned}
\text { Pendapatan } & =\mathrm{TP}-\mathrm{TB} \\
& =\operatorname{Rp} 111.937-\mathrm{Rp} 95.270 \\
& =\operatorname{Rp} 16.667 / \text { hari }
\end{aligned}
$$

Jadi Pendapatan Perbulan $=$ Rp 16.667 X 30 = Rp 500.000

b.) Sesudah di berdayakan:

Pendapatan $=\mathrm{TP}-\mathrm{TB}$

$$
\begin{aligned}
& =\operatorname{Rp} 142.000-\operatorname{Rp} 102.000 \\
& =\operatorname{Rp} 40.000
\end{aligned}
$$

Jadi Pendapatan Perbulan $=$ Rp 40.000 X 30 = Rp 1.200.000

2. a.) Sebelum di berdayakan:

$$
\begin{aligned}
\text { Pendapatan } & =\mathrm{TP}-\mathrm{TB} \\
& =\operatorname{Rp} 147.017-\mathrm{Rp} 120.350 \\
= & \operatorname{Rp} 26.667
\end{aligned}
$$

Jadi Pendapatan Perbulan $=$ Rp 26.667 X $30=$ Rp 800.000

b.) Sesudah di berdayakan:

Pendapatan $=\mathrm{TP}-\mathrm{TB}$

$$
\begin{aligned}
& =\operatorname{Rp} 228.000-\operatorname{Rp} 178.000 \\
& =\operatorname{Rp} 50.000
\end{aligned}
$$

Jadi Pendapatan Perbulan Rp 50.000 X $30=$ Rp 1.500.000

3. a.) Sebelum di berdayakan:

$$
\begin{aligned}
\text { Pendapatan } & =\mathrm{TP}-\mathrm{TB} \\
& =\mathrm{Rp} 97.500-\mathrm{Rp} 87.500 \\
& =\operatorname{Rp} 10.000
\end{aligned}
$$

Jadi Pendapatan Perbulan Rp 10.000 X $30=$ Rp 300.000

b.) Sesudah di berdayakan:

$$
\begin{aligned}
\text { Pendapatan } & =\mathrm{TP}-\mathrm{TB} \\
& =\operatorname{Rp} 206.667-\mathrm{Rp} 165.000 \\
& =\operatorname{Rp} 41.667
\end{aligned}
$$


Jadi Pendapatan Perbulan Rp 41.667 X $30=$ Rp 1.250.000

4. a.) Sebelum di berdayakan:

$$
\begin{aligned}
\text { Pendapatan } & =\mathrm{TP}-\mathrm{TB} \\
& =\operatorname{Rp} 110.683-\mathrm{Rp} 92.350 \\
& =\operatorname{Rp} 18.334
\end{aligned}
$$

Jadi Pendapatan Perbulan Rp 18.334 X 30 = Rp 550.000

b.) Sesudah di berdayakan:

$$
\begin{aligned}
\text { Pendapatan } & =\mathrm{TP}-\mathrm{TB} \\
& =\operatorname{Rp} 332.417-\operatorname{Rp} 265.750 \\
& =\operatorname{Rp} 66.667
\end{aligned}
$$

Jadi Pendapatan Perbulan Rp 66.667 X $30=$ Rp 2.000.000

Dari data tabel bantuan usaha pemerintah diatas dapat dilihat bahwa pemerintah dalam memberikan bantuan usaha kepada masyarakat dapat dikatakan berhasil dalam memberikan motivasi dan pelatihan yang baik bagi masyarakat. Dengan adanya bantuan usaha, masyarakat mampu berkembang sesuai dengan potensi yang dimiliki karena bantuan usaha dari pemerintah sangat membantu masyarakat dalam meningkatkan pendapatan masyarakat. Dalam membangun perekonomian masyarakat peran pemerintah sangatlah berpengaruh penting dalam memberikan motivasi dan pelatihan yang baik. Dengan adanya bantuan usaha pemerintah maka masyarakat akan mampu untuk diberdayakan. Terbukti bahwa dari hasil pengamatan penulis, setiap bantuan usaha pemerintah yang ada di kecamatan dan kelurahan bara masyarakat mampu untuk mengelola hasil usaha yang diberikan pemerintah untuk itu pemerintah sebagai pasilitator harus bisa memberikan kontribusi penting dalam menjalankan setiap bantuan usaha sehingga masyarakat akan mudah untuk mengelola hasil usaha dan dapat meningkatkan penghasilan dan nilai tambah bagi masyarakat. Untuk dapat berkembang sesuai dengan potensi yang dimiliki pemerintah dalam memberikan pelatihan bagi masyarakat harus mampu memberikan pengarahan yang baik agar masyarakat bisa berkembang sesuai dengan potensi yang dimiliki.

C. Dampak Pemberdayaan Pemerintah Terhadap Peningkatan Ekonomi

Dampak secara sederhana diartikan sebagai pengaruh atau akibat yang ditimbulkan dalam setiap masalah yang terjadi baik itu dampak positif maupun negatif yang berproses pada lanjutan maupun dampak dari sebuah pelaksanaan. ${ }^{42}$ Menurut Rahmawati Rahim mengatakan

\footnotetext{
Cet. 1 h 249
}

${ }^{42}$ Sunyoto Usman Pembangunan dan Pemberdayaan Masyarakat (Yogyakarta: Pustaka Pelajar 2012) 
bahwa dampak pemberdayaan pemerintah terhadap peningkatan ekonomi sangatlah berdampak positif dengan melihat salah satu jenis bantuan usaha yang sudah terlaksana dapat memberikan sebuah nilai tambah yang baik bagi masyarakat karena bantuan usaha tersebut sangat membantu masyarakat dalam meningkatkan pendapatan usaha yang baik bagi masyarakat. $^{43}$

Data diatas menjelaskan bahwa dampak yang ditimbulkan bagi pemerintah sangatlah berpengaruh positif karena dengan melihat upaya yang telah dilakukan pemerintah dalam meningkatkan pemberdayaan ekonomi bagi masyarakat sangatlah memberikan arah yang baik sehingga pemerintah dianggap mampu dalam memberikan dorongan serta upaya yang membuat masyarakat dapat mengembangkan setiap potensi usaha yang baik bagi masyarakat. Upaya yang dilakukan pemerintah dalam pemberdayaan masyarakat yaitu sangat berproses pada perubahan peningkatan ekonomi tradisional ke ekonomi moderen sehingga untuk melakukan perubahan tersebut langkah yang harus diambil bagi pemerintah adalah berada pada sistem pengalokasian sumber daya, penguatan kelembagaan, serta pemberdayaan sumber daya manusia. ${ }^{44}$ Adapun langkah-langkah strategis dalam pemberdayaan masyarakat yaitu pemerintah harus mampu meningkatkan taraf akses kedalam aset usaha. Bagi setiap masyarakat yang masih dominan dalam ekonomi rakyat adalah modal produktif yang paling utama yaitu adanya usaha bagi masyarakat. Secara mendasar sesuai dengan tujuan untuk membangun kemandirian bagi masyarakat pemerintah harus mampu menggerakkan produktifitas usaha yang telah diberikan pemerintah kepada setiap masyarakat. Dalam memperkuat posisi setiap transaksi, pemerintah dalam melihat posisi dan kekuatan dalam perekonomian masyarakat sangatlah lemah. Untuk itu pemerintah dalam meningkatkan tugas dan keterampilan masyarakat harus bisa mengatur sistem perekonomian masyarakat dengan baik agar masyarakat akan memiliki kemampuan dalam menjalankan setiap bantuan usaha. ${ }^{45}$

Dari pembahasan hasil penelitian diatas maka penulis akan mengaitkan setiap jumlah rumusan masalah tersebut kemudian dari hasil penelitian tersebut penulis akan menarik sebuah kesimpulan dari setiap jumlah rumusan masalah yang ada. Adapun kesimpulan penulis mengenai pembahasan hasil penelitian dalam setiap pandangan penulis melihat bahwa di Kecamatan Bara Kota Palopo sebelum adanya bantuan pemerintah dari data yang penulis

\footnotetext{
${ }^{43}$ Rahmawati Rahim, S. AN Operator Computer Kantor Kel Belandai, (Wawancara Tanggal 13 Januari 2016)

${ }^{44}$ Armia Karim, SE. Kepala Seksi Pembangunan Dan Perekonomian dan Kesos Kecamatan Bara, (Wawancara Tanggal 11 Januari 2016)

${ }^{45}$ Totok Mardikanto dan Poerwoko Soebiato,op.cit h 172-175
} 
dapatkan bahwa setiap kondisi perekonomian masyarakat sebelum adanya bantuan berupa modal usaha dari pemerintah, kondisi perekonomian masyarakat belum sepenuhnya baik dikarenakan masyarakat sangatlah kesulitan untuk memenuhi setiap kebutuhan dalam ekonomi. Salah satu faktor utama yang sangat menghambat perekonomian masyarakat yaitu kurangnya modal usaha yang mengakibatkan masyarakat sangat kesulitan dalam mengatur setiap perekonomiannya. Dengan adanya strategi yang dilakukan pemerintah dalam membangun perekonomian masyarakat maka upaya yang dilakukan pemerintahan kecamatan dan kelurahan bara dalam memberikan motivasi dan pelatihan kepada setiap masyarakat yaitu dengan melakukan program UB usaha bersama yang disediakan oleh pemerintah kecamatan dan kelurahan bara. Pemerintah dalam memberikan bantuan usaha kepada masyarakat sangatlah terbukti bahwa masyarakat mampu dalam mengelola setiap bantuan usahanya sehingga upaya yang dilakukan pemerintah dalam memberikan motivasi dan pelatihan yang baik dapat membuat perekonomian msyarakat menjadi maju dan berkembang disamping dapat menambah tingkat pendapatan masyarakat dapat juga menambah nilai tambah bagi setiap masyarakat. Adapun usaha pemerintah yang mampu menambah tingkat pendapatan masyarakat diantaranya yaitu usaha warung jualan, usaha penjualan keripik, usaha penjualan ikan, usaha mesin jahit, usaha petani sayur, usaha seribu kandang ayam, dan usaha perbengkelan. Dalam meningkatkan pemberdayaan masyarakat upaya pemerintah dalam mensejahterakan masyarakat sangatlah berdampak positif karena pengelolaan setiap bantuan usaha sangatlah mendorong dan memotivasi masyarakat untuk mampu dalam mengelola setiap bantuan usaha yang diberikan pemerintah sehingga potensi masyarakat untuk berkembang sangat terbukti dapat memberikan arah yang baik dalam membangun perekonomian masyarakat.

\section{Kesimpulan}

Berdasarkan hasil penelitian yang telah dilakukan tentang "Strategi Pemerintah Dalam Upaya Meningkatkan Pemberdayaan Ekonomi Masyarakat Di Kecamatan Bara Kota Palopo" maka pada Bab ini peneliti dapat memperoleh kesimpulan dan saran sebagai berikut:

1. Salah satu kondisi sosial ekonomi masyarakat kecamatan bara sangatlah menjanjikan bagi setiap usaha dengan melihat keterbukaan masyarakat mengenai bantuan usaha maka masyarakat akan mampu untuk berkembang sesuai dengan potensi yang dimiliki dengan adanya bantuan usaha pemerintah sangatlah mengharapkan bagi setiap 
masyarakat agar mampu dalam mengelola setiap bantuan usahanya dengan baik disamping dapat menjadi motivasi dapat juga menjadi pelatihan dan nilai tambah bagi masyarakat sehingga mampu untuk meningkatkan pendapatan dan kesejahteraan masyarakat dapat terwujud dengan baik.

2. Adapun strategi pemerintah dalam pemberdayaan masyarakat kecamatan bara yaitu dengan adanya strategi yang dilakukan pemerintah dalam memberdayakan masyarakat maka masyarakat akan mampu untuk berkembang adanya bantuan usaha yang telah dilakukan pemerintah sangatlah terbukti mampu meningkatkan dan mensejahtrakan pendapatan masyarakat. Dari hasil penelitian langsung adapun jenis bantuan usaha pemerintah yang yang dapat meningkatkan pendapatan masyarakat di kecamatan bara diantaranya yaitu:
a. Usaha Warung Jualan
b. Usaha Penjualan Keripik
c. Usaha Penjualan Ikan
d. Usaha Mesin Jahit
e. Usaha Petani Sayur
f. Usaha Seribu Kandang Ayam
g. Usaha Perbengkelan

3. Dampak pemberdayaan pemerintah terhadap peningkatan ekonomi sangatlah berdampak baik pemerintah dalam meningkatkan pendapatan masyarakat sangatlah menjanjikan bagi setiap usaha masyarakat sehingga pemerintah dalam mensejahtrakan masyarakat sangat mampu untuk membantu masyarakat dalam mengembangkan setiap potensi usahanya dengan baik adanya bantuan usaha sangatlah terbukti bahwa pemerintah telah berhasil dalam mensejahterakan masyarakat dan mampu menambah tingkat pendapatan dan nilai tambah bagi masyarakat.

\section{Saran}

Berdasarkan yang telah diuraikan sebelumnya maka penulis memberikan saran yang mungkin dapat mengembangkan strategi pemerintah dalam upaya meningkatkan pemberdayaan ekonomi masyarakat di kecamatan bara kota palopo kedepannya yaitu sebagai berikut: 
1. Pemerintah dalam mengembangkan potensi masyarakat harus mampu memberikan motivasi dan pelatihan yang baik agar masyarakat mampu untuk berkembang dengan menjadikan usaha sebagai tingkat pendapatan masyarakat.

2. Dalam menjalankan setiap bantuan usaha upaya yang harus dilakukan pemerintah dalam mensejahtrakan masyarakat kedepannya pemerintah harus mampu untuk meningkatkan kualitas sumber daya manusia agar perekonomian masyarakat dapat menjadi maju dan berkembang.

3. Sebagai pemikir yang baik dalam meningkatkan pemberdayaan masyarakat peran pemimpin atau camat kecamatan bara sangatlah dibutuhkan dalam meningkatkan kesejahteraan masyarakat pembangunan merupakan salah satu potensi yang harus dikembangkan pemerintah agar kebutuhan ekonomi masyarakat dapat tercapai dengan baik.

\section{Daftar Referensi}

Abdad M. Zaidi Lembaga Perekonomian Ummat Di Dunia Islam (Bandung: Penerbit Angkasa 2003)

Allimin Mu', Prinsip Pemberdayaan Ekonomi Masyarakat Ditinjau Dari Syari'at Islam (Skripsi Stain Palopo Tahun 2013)

Aedy Hasan Teori dan Aplikasi Pembangunan Perspektif Islam (Yogyakarta: Graha Ilmu 2011)

Ajho Firdaus, Pemberdayaan Masyarakat dalam http://firdausajho.Blogspot. co.id/(Akses tgl 02 oktober 2015)

Arsip data program dan kegiatan kecamatan bara tahun 2012, 2013 dan 2015

Awang Azam Implementasi Pemberdayaan Pemerintah Desa (Yogyakarta:Pustaka Pelajar 2010)

Burhanuddin dkk. Ekonomi Islam (Jakarta: Rajawali Pers. 2011)

Daniel Moehar, Metode penelitian sosial ekonomi (Jakarta: Penerbit Bumi Aksara 2002-2003)

Daniel Sulekale Dalle, Pemberdayaan Masyarakat Miskin Di Era Otonomi Daerah http://emperordeva.wordpress.com (Akses tgl 02 oktober 2015)

Darrussalam, ayat-ayat Al-Quran tentang sosial masyarakat dalam https:// bidsosdarussalam. wordpress. com. (Akses tgl 26 juni 2015)

Erniyati, Strategi pemberdayaan masyarakat melalui program pemberdayaan masyarakat http://repository.Uinjkt.ac.id (Akses tgl 06 agustus 2015) 
Fattah Sanusi dkk, Ilmu Pengetahuan Sosial (Jakarta: PT. Ghalia Indonesia Printing 2008)

Herimanto dkk, Ilmu sosial dan budaya dasar (Jakarta:PT Bumi Aksara)

HR. Bukhari, no. 1470; Muslim, no. 1042; Tirmidzi, no. 680 dan Nasa-i, V/96.

Jasin Musafir dan Taufik, Opini palopo darurat kemiskinan http://luwuraya com (Akses tgl 01 oktober 2015)

Kamil-Al Ri Agama Depertemen, Al-Quran dan terjemahannya (jakarta timur: edisi tahun 2002 CV Darus Sunnah 2008)

Mardikanto Totok dan Poerwoko Soebiato pemberdayaan masyarakat dalam perspektif kebijakan publik (Bandung: Alfabeta 2013 cet. 11)

Menurut L.C Maleong dalam Lestari (2013)

Muqtafiah, Upaya Pemerintah Dalam Mengoptimalkan Pengembangan Usaha Mikro Kecil Dan Menengah (UMKM). Dalam http://muqtafiah.blogspot.co.id. (Akses tgl 15 oktober 2015)

Munjazi Syukron, Pemberdayaan masyarakat untuk mengurangi kemiskinan melalalui program nasional pemberdayaan masyarakat PNPM mandiri (Skripsi Universitas Islam Negeri Sunan Kalijaga Yogyakatra Tahun 2009)

Peraturan mentri dalam negeri, tentang kader pemberdayaan masyarakat dalam file:///C:users/user/downloads/no_7_2007\%20(3). pdf (Akses tgl 09 november 2015)

Peraturan pemerintah repoblik Indonesia, Undang-undang pemerintah kecamatan No 19 tahun 2008 file:///C:/users/user/downloads/peraturan pemerintah tahun 2008-01908\%20(4).pdf (Akses tgl 09 november 2015)

Rahmat Aliaman, warga miskin capai 15.500 jiwa http://palopopos.co.id/ headline/ item/1303.html. (Akses tgl 07 desember 2015)

Rangkuti Freddy, Analisis SWOT Teknik Membedah Kasus Bisnis (Jakarta: PT Gramedia Pustaka Utama 2004)

Rivai Veithzal dkk, Islamic Leadership (Jakarta: PT Bumi Aksara)

Shihab M. Quraish, Tafsir al-Mishbah Pesan kesan dan Keserasian al-Qur'an Surah AlJumu'ah (Jakarta:Penerbit Lentera Hati 2002) h 229-232

Sinin Abu Ahmad Ibrahim, Manajemen Syariah (Jakarta: Grafindo PT Raja Persada 2006)

S. Nasution, Metode Research Penelitian Ilmiah (Jakarta: PT Bumi Aksara 2008 Ed.1 Cet.10)

Said Farid A. Muhammad, Strategi pemberdayaan UMKM pada dinas koperindag kabupaten maros studi kasus pada sektor perdagangan (Skripsi Universitas Hasanuddin Tahun 2015)

Sulistiyani, Pemberdayaan Masyarakat http://cikacimoet. Blogspot.co.id (Akses tgl 08 juni 2015) 
Taqdir Mety, Qodratillah Dkk, Kamus bahasa indonesia untuk pelajar (Jakarta: Badan pengembangan bahasa kementrian pendidikan dan kebudayaan 2011 Ed. 1 Cet. 1)

Usman Sunyoto Pembangunan dan Pemberdayaan Masyarakat (Yogyakarta: Pustaka Pelajar 2012) Cet. 1 h 249

Wahyu Ramdani, Isd ilmu sosial dasar (Bandung: Pustaka Setia 2007)

Wahyudi Agustinus Sri Manajemen Strategik (Tangerang Selatan: BinaRupa Aksara publisher 2002) h 180

Widjaja Haw, Penyelenggaraan otonomi di Indonesia dalam rangka sosialisasi UU No. 32 Tahun 2004 tentang pemerintahan daerah (Jakarta: PT Raja Grafindo Persada 2007)

Wibowo, Perilaku Dalam Organisasi (Jakarta: PT Rajawali Pers 2014)

Winarno Surkhmad, Pengantar Penelitian Ilmiah Dasar Metode Dan Teknik (Bandung: Penerbit Tarsito 2001)

Wybisana Goenawan, Pemberdayaan dalam perspektif islam http://www.ristek.go.id (Akses $\operatorname{tgl} 06$ agustus 2015)

Zimmerer Thomas W. dkk. Kewirausahaan dan Manajemen Usaha Kecil. (Jakarta: Penerbit Salemba Empat 2008) 